\title{
РЕЦЕНЗІЯ
}

\section{на підручник «Медична мікробіологія, вірусологія та імунологія»}

\section{для студентів вищих медичних закладів IV рівня акредитації / За ре- дакцією академіка НАН, НАМН України В.П. Широбокова. - Вінниця: Нова книга, 2011. - 952 с.: іл.}

Соціальний запит сьогоднішнього суспільства України потребує покращення якості медичної допомоги, наближення іії до європейських і світових стандартів. Для вирішення цього запиту необхідне не лише високе матеріально-технічне забезпечення лікувально-профілактичних закладів, але й високоваліфіковані медичні працівники. Підготовка лікарів проводиться у вищих медичних освітніх закладах згідно з положеннями «Закону про освіту» та інших правових документів.

Актуальним завданням вищої медичної освіти України є підготовка ерудованих, високоосвічених і здатних до конкуренції на європейському просторі лікарів, фармацевтів. Значною мірою цей процес залежить від забезпечення вищих навчальних закладів сучасною навчальною літературою, яка сприяє опануванню новітніми досягненнями медичної науки, особливо фундаментальної. Однією із складних інформаційнонасичених дисциплін сьогодення є медична мікробіологія, що бурхливо розвивається. Оволодіння знаннями з медичної мікробіології, вірусології та імунології є важливою складовою у формуванні лікарського мислення. Без знання предмета складно науково обгрунтувати етіопатогенез, діагностику, лікування та профілактику інфекційних захворювань. Мікробіологія є базовим предметом для клінічних та медико-профілактичних дисциплін логічного клінічного мислення. Сучасний фахівець у галузі медицини має володіти значним запасом знань, уміти поповнювати, розвивати, творчо застосовувати їх у повсякденній діяльності. Тому існує необхідність в якісній підготовці студентів, яка базується на теоретичних та фахових знаннях і потребує якісної навчальної та наукової літератури.

Сьогодні назріла потреба у створенні вітчизняного широкомасштабного, грунтовного сучасного підручника з медичної мікробіології, вірусології та імунології для студентів медичних вишів України. Надії та сподівання педагогів, науковців, практичних лікарів збулися з виходом у світ у 2011 р. фундаментальної праці «Медична мікробіологія, вірусологія та імунологія» для студентів вищих медичних закладів IV рівня акредитації за редакцією відомого у світі та в Україні вченого академіка Національної академії наук України, академіка Національної академії медичних наук України Володимира Павловича Широбокова. У написанні книги взяли участь відомі провідні науковці, досвідчені педагоги, мікробіологи, вірусологи, імунологи України. Найголовнішим є те, що підручник написали у відповідності з офі- ційно затвердженими в установленому порядку навчальними програмами з мікробіології, вірусології та імунології.

Книга складається 3 передмови, переліку умовних скорочень, двох частин - «Загальна мікробіологія», «Спеціальна мікробіологія»; двох додатків - «Основні патогенні бактерії, віруси, мікроскопічні гриби та найпростіші і захворювання, які вони спричиняють», «Словник термінів 3 мікології», списку літератури, предметного, іменного покажчиків; покажчика латинських назв мікроорганізмів, гельмінтів. Слід підкреслити позитивну перевагу цього підручника перед іншими виданнями для студентів медичних університетів. Книга переконливо переважає англомовні закордонні підручники з мікробіології для студентів.

У першій частині видання вдало розглянуто питання загальної мікробіології, а саме: сучасні методи дослідження мікроорганізмів, морфологія, структура і міжнародна класифікація бактерій; фізіологія бактерій. Особливої уваги заслуговує розділ, присвячений зв'язку сучасної медичної мікробіологічної науки із фундаментальними, клінічними дисциплінами. Надзвичайно важливим для лікарів $є$ матеріал, присвячений розвитку i становленню української мікробіологічної науки. Цінність нового видання полягає в тому, що в ньому вперше широко представлено розділ «Вплив фізичних, хімічних та біологічних факторів на мікроорганізми». Вплив цих факторів на мікроорганізми має винятково важливе практичне значення для біотехнологічних процесів, а також для розробки заходів боротьби із збудниками інфекційних хвороб. У розділі чітко, конкретно, доступно, логічно, грунтовно подані визначення основних понять асептики, антисептики, дезінфекції, стерилізації; наведені методи, засоби, переваги та недоліки. Ці базові знання є важливими для студентів усіх факультетів медичного вишу.

Важливою перевагою рецензованого підручника $є$ доступність подання матеріалу в розділі «Генетика мікробів». У ньому всі положення висвітлені на високому науковому зрозумілому для читачів рівні. Вперше в підручнику зразково представлена інформація про генетику вірусів, їх мінливість. Практичним лікарям стане в нагоді матеріал про сучасні генетичні методи, які використовують для діагностики інфекційних хвороб: полімеразна ланцюгова реакція, рестрикційний аналіз, метод молекулярної гібридизації тощо. Корисним для студентів усіх спеціальностей $\epsilon$ розділ «Біотехнологія». Сучасна медицина не обходиться без використання біотехнологічних 
процесів для створення лікарських, діагностичних, профілактичних препаратів. Використання генно-інженерних мікробних ферментів, речовин, продуктів, принципи їх отримання застосування мають високу цінність для практичних лікарів.

Автори провели значну роботу щодо систематизації існуючих підходів до класифікації, механізмів дії протимікробних препаратів. Окрім класичного викладу матеріалу стосовно визначення, класифікації протимікробних препаратів у підручнику вперше органічно представлено антисептики, дезінфектанти, антивірусні препарати, принципи раціональної антибіотикотерапії. Систематизація матеріалу з теорії і практики хіміотерапії $\epsilon$, безумовно, актуальною і своєчасною. У підручнику автори грунтовно розглядають питання імунології: неспецифічну резистентність організму, вчення про антигени, імунну систему організму, типи імунної відповіді, реакції імунітету, алергію та інші. Особливої уваги заслуговують розділи «Імунодіагностика та імунокорекція», «Імунопрофілактика та імунотерапія». Мікробіологічна наука зробила велетенські кроки у розробці, вдосконаленні цих наукових напрямків. Новизною книги $\epsilon$ представлення матеріалу «Принципи і засоби імунокорекції. Імуномодулятори, імуносупресори», що має важливе значення для практичної медицини. Вперше в підручнику 3 медичної мікробіології систематизовано на високому рівні відомості про вакцинні препарати, наведено методи їх одержання, календар проведення щеплень. Цей розділ є прекрасною базою для продовження навчання студентів із клінічної імунології та алергології.

Друга частина навчального видання містить надзвичайно актуальний розділ «Мікробіологічна діагностика інфекційних захворювань». У ньому автори систематизували та логічно виклали матеріал стосовно завдань, облаштування базових, режимних та інших лабораторій; правила і режим роботи в мікробіологічній лабораторії; групи патогенних мікроорганізмів. Належну увагу приділено перевагам та недолікам мікроскопічного, культурального, серологічного, алергологічного, біологічного, експрес-методів діагностики захворювань. Вміло розкрито особливості та сутність вірусологічних методів дослідження; мікробіологічної діагностики мікозів; протозойних інфекцій, а також захворювань, спричинених мікроорганізмами, що культивуються на штучних поживних середовищах. Висвітлено напрями удосконалення отримання достовірних результатів за допомогою генетичних досліджень. Опанування знаннями з вказаного розділу дозволить студентам та практичним лікарям мати цілісну картину про доцільність вибору методів діагностики інфекційних хвороб.

Вперше у вітчизняному підручнику з медичної мікробіології представлений розділ з гельмінтології, що є досить актуальним. Так, щорічно рівень захворюваності на гельмінтози населення України сягає до 900 на 100 тисяч населення.
Розділ, в якому розглядають біологічні властивості збудників та захворювання, які вони викликають, класифікацію та показання до використання антигельмінтних препаратів написано доступно, логічно, гарно, всебічно. На всіх рівнях підготовки висококваліфікованих медичних кадрів стоїть питання вивчення клінічної мікробіології, яке націлене на ефективне поєднання теоретичних знань 3 практичною підготовкою та підвищенням якості медичної освіти. Можна вітати колектив авторів підручника із грунтовним висвітленням матеріалу $з$ клінічної та санітарної мікробіології, ролі мікроорганізмів у виникненні опортуністичних, внутрішньолікарняних інфекцій. Цікавим і корисним для читачів є розділ про мікробіологічні ознаки збудників опортуністичних інфекцій, у якому висвітлені особливості контролю в системі заходів профілактики інфекцій.

Принципово новими у підручнику з медичної мікробіології $є$ розділ «Мікроорганізми і плід». Значення і необхідність вивчення внутрішньоутробних інфекцій зумовлені можливим інфікуванням плода, мертвонародженням, невиношуванням вагітності, природженими вадами розвитку, постнатальними інфекційними захворюваннями. Студентам важливо знати основні біологічні властивості збудників цих захворювань; сучасні методи мікробіологічної діагностики, специфічну профілактику інфекційних уражень плода. Високої оцінки заслуговує розділ «Мікробіологічні дослідження у фармації». Поданий матеріал дозволяє цілісно засвоювати знання 3 мікробіології. У ньому систематизовано відомості про фітопатогенні мікроорганізми, діагностику інфекційних хвороб рослин, мікробіологічні дослідження лікарської сировини, готових лікарських форм. Беззаперечно позитивним $є$ підрозділ «Мікробіологічний контроль лікарських засобів в умовах аптечного виробництва та фармацевтичних підприємств» згідно $з$ діючою Фармакопеєю України. Новизною відрізняються погляди авторів підручника на висвітлення розділів «Нормальна мікрофлора тіла людини»; «Мікрофлора ротової порожнини». В єдиному комплексі кваліфіковано подано інформацію щодо мікроорганізмів, які заселяють біотопи організму людини, їх роль у життедіяльності організму людини; причини виникнення порушень екосистем, ролі місцевого імунітету, засобів профілактики та лікування.

Перевагою даного підручника можна вважати те, що автори дають чіткі визначення наукових термінів, які використовують у мікробіології, вірусології та імунології. Кращому засвоєнню читачами матеріалу, більшій його наочності та підвищенню ефективності освоєння предмета сприяють додатки про основні збудники захворювання, які вони спричиняють; словник мікологічних термінів. Після кожного розділу наведені контрольні питання для самоперевірки, що заслуговує на позитивну оцінку. Окремо слід відзначити ретельно складені таблиці, схеми, малюнки, світлини, які дозволяють краще опанувати меди- 
чну мікробіологію. Підручник дозволяє студентам підвищити якість самостійного вивчення предмета згідно з вимогами Закону про вищу освіту України.

За актуальністю, новизною, змістом, структурою, повнотою, логікою та послідовністю викладу підручник «Медична мікробіологія, вірусо- логія, імунологія» $є$ оригінальним сучасним виданням, яке має безперечну наукову та практичну цінність і заслуговує високої оцінки. Книга є корисною для студентів, викладачів, науковців, аспірантів, магістрантів, інтернів, та всіх фахівців, які забезпечують протиепідемічне благополуччя нашої держави.

Член-кореспондент академії педагогічних наук Украӥни, лауреат Дерэсавної премії Украӥни в галузі науки і техніки, доктор медичних наук, професор Василь Павлович Пішак Професор кафедри мікробіології, вірусології та імунології Вищого держсавного навчального закладу Украӥни “Буковинський державний медичний університет”, доктор медичних наук, професор Ігор Йосипович Сидорчук

Buk. Med. Herald. - 2016. - Vol. 20, № 1 (77). - P. 270-273 Надійшла до редакції 11.02.2016 року 